kangaroo rats, genus Dipodomys. Proc. Biol. Soc. Washington, 78:49-54.

1978. Kangaroo rats: intraspecific variation in Dipodomys spectabilis Merriam and Dipodomys deserti Stephens. Illinois Biol. Monogr., 49:1-116.

NIE, N. H., ET AL. 1975. Statistical package for the social sciences. McGraw-Hill Book Co., New York, 675 pp.
Patton, J. L. 1973. An analysis of natural hybridization between the pocket gophers, Thomomys bottae and Thomomys umbrinus, in Arizona. J. Mamm., 54:561-584.

Petersen, M. K. 1976. Noteworthy range extensions of some mammals in Durango, Mexico. Southwestern Nat., 21:139-142.

John O. Matson, The Museum, Michigan State University, East Lansing, MI 48824. Submitted 10 April 1979. Accepted 2 September 1979.

J. Mamm., 61(3):563-566, 1980

\title{
MAMMALS COLLECTED BY THE MENAGE SCIENTIFIC EXPEDITION TO THE PHILIPPINE ISLANDS AND BORNEO, 1890-1893
}

The mammals of the Philippines and Borneo are poorly known, partly because of inadequate collecting but also because extant specimens have not been thoroughly reported. We recently rediscovered a large collection of mammals obtained from this region in the early 1890's by the Menage Scientific Expedition. This collection contains many specimens of rare or inadequately studied species. The purposes of this report are: 1) to call attention to the existence of this collection and to some preliminary published (mostly in obscure places) information on the specimens and the natural history of the species obtained; 2 ) to present previously unpublished information on the exact localities, numbers of specimens taken, and the historical abundance of some species, information which we have gleaned from study of original field notes and catalogs; 3) to outline briefly the history of this poorly known expedition, including a partial explanation for its obscurity.

Some of the mammals collected by the Menage Expedition were sold to the Field Museum of Natural History in 1895. Elliot $(1896,1907)$ listed these specimens along with localities. Hollister (1912) was aware that the Menage Expedition had collected in the Philippines. He cited records from an early partial list of the species obtained (Bourns and Worcester, 1894) and from a popular book written by Worcester (1909). In his Philippine Land Mammals, Taylor (1934:26) mentioned that "a small collection was made by the Menage Expedition to the Philippines. I have been unable to trace this material, but some of it is at present in the museum of the University of Minnesota." Taylor cited the preliminary note on the Menage collection by Bourns and Worcester (1894) and both papers contributed by Elliot (1896, 1907). However, for several taxa mentioned only by Bourns and Worcester (1894), Taylor (1934) was not sure what species had actually been obtained. Medway (1977) made no mention of the Menage Expedition in Mammals of Borneo.

In $1890 \mathrm{Mr}$. Louis F. Menage, a financier dealing with real estate and loans, from Minneapolis, Minnesota, agreed to sponsor an expedition to the Philippine Islands under the auspices of the Minnesota Academy of Natural Sciences, for "the purpose of collecting natural history specimens" (Anonymous, 1891:301). Menage contributed $\$ 10,000$ for the expenses of the expedition with the agreement that his name would be associated with it (Gale, 1910). The Academy agreed to oversee organization of the trip and deposition of specimens collected. The expedition was to be known officially as "The Menage Scientific Expedition to the Philippine Islands." Dean C. Worcester and Frank S. Bourns were contacted to do the field collecting and agreed under the condition that they could "control the description of new species, more particularly in the line of birds ..." (Anonymous, 1891:302). Both men had experience collecting in the Philippines with the Steere Expedition in 1887-88 (Steere, 1890). Worcester and Bourns arrived in the Philippine Islands on 6 September 1890 and continued their collecting there and on Borneo for the next 29 months, visiting 19 islands in all: Basilan, Borneo, Busuanga, Cebu, Culion, Guimaras, Luzon, Mindanao, Mindoro, Negros, Palawan, Panay, Romblon, Samar, Sibuyan, Siquifor, 
Sulu, Tablas, and Tawi Tawi. Their primary emphasis was on collecting birds, but mammals, reptiles, invertebrates (primarily mollusks), and anthropological artifacts were obtained whenever possible. Some 4,000 specimens of birds and more than 500 mammals were obtained. Worcester and Bourns returned to Minneapolis in the summer of 1893 and intended to begin work immediately on their material. However, a major national financial crisis that year caused largely by economic panic resulted in Menage fleeing to South America after charges were lodged against him concerning four million dollars in fraudulent loan notes. Bourns and Worcester (1894:6) wrote "the financial troubles prevailing at that time had seriously embarrassed many friends of the Academy ...." As a result of Menage's financial difficulties, funds were not available to ensure that specimens were properly curated and reported upon.

While collecting in the Philippines, both Worcester and Bourns wrote numerous reports to the Minnesota Academy of Natural Sciences in the form of letters. The originals of these and much of the other early correspondence regarding the expedition currently are on file in the Minneapolis History Collection of the Minneapolis Public Library. The letters contain a detailed itinerary and numerous notes concerning the animals observed and collected, and are rich in local accounts of the native fauna. Additionally, the editor of the Academy's bulletin series felt that excerpts of many letters were of sufficient general interest to be published (Worcester and Bourns, 1910). An excellent map of the Philippines, including some detailed information on collecting localities, was made available by Worcester and Bourns (1898).

Dean C. Worcester continued his scholarly pursuits, returning to the University of Michigan, where he earned a D.Sc. degree and became Curator of the Zoological Museum. President McKinley appointed him a member of the U.S.-Philippine Commission after the Spanish-American War. In addition to writing several scientific articles, mostly on birds, Worcester wrote three books: The Philippine Islands and their people (1899); The non-Christian tribes of northern Luzon (1906); and The Phillipines past and present (1913). Additional information concerning Worcester was published by T. S. Palmer (1924). Frank S. Bourns also attended the University of Michigan for his undergraduate work. After returning from the Menage Expedition, he completed his M.D. and practiced medicine in Ann Arbor.

The more than 500 mammal specimens of the Menage Collection were brought to Minneapolis, then dispersed as follows: 1) 19 specimens were given to Henry Nachtrieb, President of the Minnesota Academy of Sciences and Chairman of the Zoology Department, University of Minnesota, for the university's collections; 2) 42 were given to Henry Osborn, Hamline University, St. Paul, Minnesota; 3) 45 were sold to the Field Museum of Natural History (FMNH) in 1895; 4) five orangutans and one proboscis monkey were mounted for the Minnesota Academy of Natural Sciences; 5) one specimen was given to Ward Natural Science Establishment, Rochester, New York, in exchange for mounting orangutans; 6) 10 specimens were shipped to Rowland Ward \& Co., London, England, in 1898; 7) three were recorded as "Shipped to Dublin-5/20/ 1898 "; 8) the remaining specimens apparently were retained by the Academy of Natural Sciences. These were given to the Minneapolis Public Library when the Academy disbanded, and most were then given to the Bell Museum in the 1950's. While returning to Minneapolis, Bourns stopped at the British Museum and Worcester stopped in Japan and the Hawaiian Islands, where they were reported to have "made arrangements for exchanges" (Anonymous, 1893:31), but we can find no other evidence that Menage specimens were deposited at these places.

We have located 125 specimens in the Bell Museum of Natural History (MMNH), 33 in the Field Museum of Natural History, and 1 Nycticebus at Western New Mexico University (WNMU). Some of the specimens retained by the Academy and possibly some of those given to Hamline University are now incorporated into the Bell Museum collection. Some specimens given to Hamline are known to have been discarded, and none remained there in 1978. Also, Roberts (1939) implied in his annual report to the University of Minnesota that some Menage materials were discarded by the Bell Museum. It appears unlikely that many of the other specimens still exist.

In the following accounts of mammals collected by the Menage Expedition, we have followed Alcasid (196-) and Medway (1977) in the use of scientific names of Philippine and Bornean mammals, respectively, unless otherwise noted, and list localities where the specimens were obtained, note present status of the specimens, and when possible provide miscellaneous notes on natural history and local abundance at the time of the expedition. The locality listed as "Calamianes" refers to both the islands of Busuanga and Culion. On the island of Borneo, Bourns 
collected at Sebangan $\left(1^{\circ} 35^{\prime} \mathrm{N}, 110^{\circ} 45^{\prime} \mathrm{E}\right)$ and along the Sibuyan River and an unnamed stream that flows into the Sadeng River near its mouth. The region collected was from $1^{\circ} 15^{\prime} \mathrm{N}$ to $1^{\circ} 35^{\prime} \mathrm{N}$ and $110^{\circ} 45^{\prime} \mathrm{E}$ to $111^{\circ} \mathrm{E}$. Specimens from this area are listed as being from Sarawak, Malaysia. Menage specimens in the Field Museum from this same region bear only the locality "Borneo." The original field catalog used by Worcester and Bourns, which contains mammals, reptiles, mollusks, and anthropological material, is on file in the mammal range of the Bell Museum.

Echinosorex gymnurus (Raffles).-Sarawak, Malaysia. Worcester and Bourns listed one "agi bulan" in their field catalog. Although the specimen no longer exists, we are certain they had obtained Echinosorex and not Hylomys because they recorded the lengths as 251/4 inches and tail as $10 \frac{1}{4}$ inches.

Cynocephalus volans Boddaert.-Basilan; Mindanao; Samar: MMNH (2), FMNH (1). Seven specimens were collected.

Pteropus hypomelanus Temminck.-Romblon: MMNH (1), complete skeleton.

Pteropus vampyrus (Linnaeus).--Romblon: MMNH (1), complete skeleton.

Acerodon lucifer (Elliot)._-Locality unknown: MMNH (2), skulls only.

Scotophilus temminckii (Horsfield).-Leyte; Panay: FMNH (5).

Tupaia palawanensis Thomas.-Calamianes; Palawan. Four specimens of Tupaia were obtained; none is known to exist today. It is unclear how many of the four were from these localities.

Nycticebus coucang (Boddaert).-Sarawak, Malaysia: FMNH (1).

Nycticebus menagensis (Lydekker).-Tawi Tawi: MMNH (15), WNMU (1), all partial or complete skeletons. These 16 specimens represent the type series (cotypes) on which the name menagensis is based. The Minnesota Academy of Natural Sciences received a letter from Worcester dated 12 November 1891 that included a description of this animal. Worcester wrote that "It is evidently one of the Lemuridae" (Worcester and Bourns, 1910:149). Professor Henry F. Nachtrieb, then President of the Academy, published Worcester's description (Nachtrieb, 1892) under the title "A new lemur (Menagensis)." Nachtrieb did not assign it to a genus, and thus the name was not available until Lydekker (1893) assigned "menagensis" to the genus Lemur. Groves (1971) considered menagensis a subspecies of $N$. coucang.

Tarsius syrichta (Linnaeus). - Samar: cited by Bourns and Worcester (1894), but none known to exist today. We have followed Hill (1955) in the use of T. syrichta, although Alcasid (196-) referred to the Philippine tarsier as T. philippinensis.

Macaca nemestrina (Linnaeus).-_Sarawak, Malaysia. Bourns and Worcester listed one "pig tailed monkey" in their field catalog; unfortunately, no specimen exists to verify the identification.

Macaca irus F. Cuvier.-Mindoro; Panay: MMNH (3), FMNH (1). The Bell Museum specimens are represented by two skeletons and a tanned skin. Bourns and Worcester (1894:61) wrote concerning this species that it "Occurs in every island visited by us. Tamed and carried everywhere by the natives." Nomenclature follows Hill (1974) rather than Alcasid (196-), who used M. mindora for populations on Mindoro and M. philippinensis for those on Panay.

Presbytis cristata (Raffles).-Sarawak, Malaysia: FMNH (2).

Presbytis melalophos (Raffles).-_Sarawak, Malaysia: MMNH (4), all tanned skins.

Nasalis larvatus (van Wurmb).-Sarawak, Malaysia: FMNH (6). Eight proboscis monkeys were collected.

Hylobates muelleri Martin.-Sarawak, Malaysia: MMNH (1), FMNH (1). Our records indicate eight were sold to the Field Museum; however, Elliot (1907) listed only one from the Menage collection. We follow Marshall and Marshall (1976) in using $H$. muelleri for the gibbons of northern Borneo.

Pongo pygmaeus (Linnaeus).-Sarawak, Malaysia: MMNH (18), FMNH (6). Forty orangutans were obtained by Bourns in January of 1893. In an interesting account of the natural history of orangutans and of an orangutan hunt, Bourns (1910:173) wrote: "between the Sarawak and the Sadeng rivers, very few if any orangs can be found. But in the adjacent territory between the Sadeng and Batang Lupar rivers, they are fairly abundant, while still farther on to the northeast they again disappear or become very scarce, the reason given being that the natives of this region use them for food and thus keep down the number. This practice is not followed in the regions about the upper Sadeng, Simunjan, and Lingga rivers." Bourns (1910:174) further noted that orangutans frequently feed "on the tender shoots of the 'bladdin,' or screw pine." He also noted that three distinct varieties of orangutans were recognized by the natives. These were "the "mias 
chappin' or largest, the 'mias rombi' or medium and the 'mias Kassa,' or smallest"' (1910:176). Bourns commented that the differences between the varieties probably have no taxonomic significance but are "partly sexual and partly accidental."

The MMNH specimens include at least partial skeletons, many of which are complete or nearly so. Ivan Suzman (pers. comm.) has informed us that ours is one of the better ontogenetic skeletal collections of Pongo from natural populations.

Manis javanica Desmarest.-Busuanga: MMNH (5). Eight specimens were obtained, including animals from Calamianes and Palawan (Bourns and Worcester, 1894). We follow Medway $(1969,1977)$ in the use of this name combination. Alcasid (196-) referred to this species as Paramanis culionensis, apparently following Lawrence (1939).

Ratufa affinis (Raffles)._Sebangan, Malaysia: MMNH (1), skull only.

Callosciurus $s p$.-Sarawak, Malaysia: MMNH (2), skulls only. Our skulls may be either $C$. notatus or C. nigrovittatus.

Sundasciurus mindanensis (Steere).-Basilan; Mindanao. Reported by Bourns and Worcester (1894), but no specimens are known to exist today and specific identifications were never verified to our knowledge. Sundasciurus is used instead of Callosciurus in accordance with Moore (1958).

Sundasciurus mollendorfii (Matschie).-Culion: MMNH (1), complete skeleton.

Sundasciurus samarensis (Steere).-Samar. Bourns and Worcester (1894); we have no verification of the identification.

Sundasciurus steerii (Günther)._Palawan. Bourns and Worcester (1894), but again the identification is unverified.

Nannosciurus concinnus (Thomas).-Basilan; Mindanao. Bourns and Worcester (1894); no specimens known to exist.

Petaurista petaurista (Pallas).-Sumatra: MMNH (1), complete skeleton. We cannot judge the accuracy of the locality; no other evidence that either Bourns or Worcester collected on Sumatra is available, but perhaps this specimen was purchased by them.

Hylopetes nigripes (Thomas)._Palawan: MMNH (7), includes five complete skeletons and one mounted skin with skull.

Thecurus crassispinis (Günther).-Sarawak, Malaysia: MMNH (1), FMNH (1). It is unclear whether or not the two extant specimens are the only ones of this species taken. The specimen in MMNH is a complete skeleton.

Thecurus pumilus (Günther).-Calamianes; Palawan: MMNH (5). Twenty specimens of the genus Thecurus (both T. crassispinis and T. pumilus) were obtained; most probably were $T$. pumilus (Elliot, 1896).

Trichys lipura Günther.-Sarawak, Malaysia: MMNH (1). Referred to as a hedgehog by Worcester and Bourns; two specimens were obtained.

Mustela nudipes $F$. Cuvier.-Sarawak, Malaysia: Worcester and Bourns listed one "light mink" in their field catalog. We assume they were referring to this species but the specimen apparently no longer exists. They recorded the length as $28 \frac{1}{2}$ inches and the tail as 11 inches, which further indicates their specimen was this species.

Mydaus marchei (Huet).-Busuanga, Palawan: MMNH (4), FMNH (1). The MMNH specimens are skulls only. We depart from the nomenclature used by Alcasid (196-) for the stink badgers in accordance with Long (1978).

Viverra tangalunga Gray.-Calamianes; Mindanao; Mindoro; Palawan; Panay; Siquijor. Twenty-eight specimens were collected. Localities were reported by Bourns and Worcester (1894); no specimens appear to exist today.

Paradoxurus philippinensis Jourdan.-Basilan; Sarawak, Malaysia; Mindanao; Mindoro; Negros; Palawan; Panay: MMNH (22), 19 skins and 3 skulls only. Bourns and Worcester (1894:61) wrote that this species "probably occurs on every island of any size in the group."

Arctictis binturong (Raffles).-Palawan: MMNH (1), skull only. Four specimens were collected.

Hemigalus derbyanus (Gray).-Sarawak, Malaysia: MMNH (1), complete skeleton.

Cynogale bennettii Gray.-Sarawak, Malaysia. Three specimens were collected, but apparently none exists today. Our records indicate one was sold to FMNH.

Felis minuta Temminck.-Cebu; Negros; Panay. Five were collected, but none apparently exists today. 
Sus barbatus Müller.-Calamianes; Palawan: MMNH (1), FMNH (2). See Elliot (1896) for a description of this species.

Sus celebensis Müller and Schlegel.-Mindanao; Negros; Panay; Samar; Sibuyan; Sulu; Tawi Tawi: MMNH (6); FMNH (2), all skulls only. Worcester (1909:512) wrote that "Wild hogs are very abundant on many of the islands, notably so in Tawi Tawi."

Tragulus nigricans Thomas.-Balabac: MMNH (4), 3 complete skeletons and 1 skin with partial skeleton; 8 were collected.

Muntiacus muntjak (Zimmerman).-Sarawak, Malaysia: FMNH (2).

Cervus $s p$.-Unknown locality: MMNH (1), skull only. Our specimen, a young male, is much larger than our representatives of $C$. calamianensis.

Cervus calamianensis (Heude).-Calamianes: MMNH (4, one of which is from an unknown locality); Culion: FMNH (2). Elliot (1896) described the FMNH specimens and later (1897) assigned the name $C$. calionensis to them as being representative of a new species. Both the male holotype and a female paratype are in the type cases at FMNH. The MMNH specimens agree well with measurements provided by Elliot.

Bubalus mindorensis (Heude).-Mindoro: MMNH (10), 4 complete skeletons and 6 skulls. Worcester (1909) provided a detailed description of hunting tamaraus and a useful account of their habits and habitat. Ours may be one of the best available collections of this endangered species. Bubalus is used instead of Anoa in accordance with Groves (1969).

We thank D. Burke and M. B. Haarstick of the Minneapolis Public Library for assistance with early records and correspondence of the Minnesota Academy of Natural Sciences, R. M. Schaefer for help locating several references, B. J. Hayward for verifying the Nycticebus at WNMU, P. W. Freeman and R. J. Izor for verifying the existence of specimens in the Field Museum and for comments on the manuscript, G. G. Musser for many helpful suggestions on the manuscript, L. R. Heaney for assistance with identification of several of the sciurids and review of an earlier draft of the manuscript, and C. Gobar for clerical assistance.

\section{LITERATURE CITED}

ALCASID, G. L. 196-. Checklist of Philippine Mammals. Dept. Education, Natl. Mus., Republic of the Philippines, $51 \mathrm{pp}$. (Year of publication not available from Library of Congress or Philippine National Museum.)

ANONYMOUS. 1891. (Minutes). Proc. Minnesota Acad. Nat. Sci., 3:293-316.

1893. (Minutes). Proc. Minnesota Acad. Nat. Sci., 4:1-46.

Bourns, F. S. 1910. An orang hunt in Borneo. Bull. Minnesota Acad. Nat. Sci., 4:173-181.

BOURNS, F. S., AND D. C. WORCESTER. 1894. Preliminary notes on the birds and mammals collected by the Menage Scientific Expedition to the Philippine Islands. Occas. Papers, Minnesota Acad. Nat. Sci., 1(1):1-64.

ELLIOT, D. G. 1896. On sundry collections of mammals received by the Field Columbian Museum from different localities, with descriptions of supposed new species and subspecies. Publ. Field Columbian Mus. (Zool. Ser.), 1:67-82.

- 1897. Remarks upon two species of deer of the genus Cervus from the Philippine Archipelago. Publ. Field Columbian Mus. (Zool. Ser.), 1:157.

1907. A catalogue of the collection of mammals in the Field Columbian Museum. Publ. Field Columbian Mus. (Zool. Ser.), 8:1-694.
GALE, H. 1910. Historical sketch of the Minnesota Academy of Science. Proc. Minnesota Acad. Nat. Sci., 4:430-442.

Groves, C. P. 1969. Systematics of the anoa (Mammalia, Bovidae). Beaufortia, 17:1-12. . 1971. Systematics of the genus Nycticebus. Pp. 44-53, in Taxonomy, anatomy, reproduction ( $\mathrm{J}$. Biegert and $\mathrm{W}$. Leutenegger, eds.). Proc. 3rd Internat. Congr. Primatol., 1:1-278.

HILl, W. C. O. 1955. Primates: comparative anatomy and taxonomy. II. Haplorhini: Tarsioidea. Univ. Edinburgh Press, 347 pp.

- 1974. Primates: comparative anatomy and taxonomy. VII. Cynopithecinae: Cercocebus, Macaca, Cynopithecus. Univ. Edinburgh Press, 934 pp.

HOLlister, N. 1912. A list of the mammals of the Philippine Islands, exclusive of the Cetacea. Philippine J. Sci., 7:1-64.

LAWRENCE, B. 1939. Mammals. Pp. 28-73, in Collections from the Philippine Islands ( $T$. Barbour, B. Lawrence, and J. L. Peters, eds.) Bull. Mus. Comp. Zool., 86:25-128.

LONG, C. A. 1978. A listing of Recent badgers of the world, with remarks on taxonomic problems in Mydaus and Melogale. Repts. Fauna Flora Wisconsin, 14:1-6.

LYDEKKER, R. 1893 (1892). Mammalia. Zool. Rec., 29:24-25. 
Marshall, J. T., JR., and E. R. Marshall. 1976. Gibbons and their territorial songs. Science, 193:235-237.

MEDWAY, L. 1969. The wild mammals of Malaya and offshore islands including Singapore. Oxford Univ. Press, London, $127 \mathrm{pp}$. 1977. Mammals of Borneo: field keys and an annotated checklist. Monog. Malaysian Branch Royal Asiatic Soc., 7:1-172.

MoORE, J. C. 1958. New genera of East Indian squirrels. Amer. Mus. Novitates, 1914:1-5.

Nachtrieb, H. F. 1892. A new lemur (Menagensis). Zoologischer Anzeiger, 15:147149.

Palmer, T. S. 1924. Prof. Dean Conant Worcester (Obituary). Auk, 41:645-646.

Roberts, T. S. 1939. Annual reports to the president. Ann. Mus. Nat. Hist., Univ. Minnesota (1872-1939), $183 \mathrm{pp.}$

Robert M. TIMm AND Elmer C. Birney, Bell Museum of Natural History, University of Minnesota, Minneapolis, MN 55455. (Present address of Timm: Division of Mammals, Field Museum of Natural History, Roosevelt Road at Lake Shore Drive, Chicago, IL 60605). Submitted 2 May 1979. Accepted 3 December 1979.

J. Mamm., 61(3):566-571, 1980

\section{A BLACK-FOOTED FERRET FROM KANSAS}

Only two specimens of the endangered black-footed ferret (Mustela nigripes) have been reported from Kansas since 1935 (Jones and Loomis, Trans. Kansas Acad. Sci., 56:107, 1953; Taylor, Trans. Kansas Acad. Sci., 64:41, 1961). Numerous unsubstantiated sightings of ferrets, some accompanied by detailed descriptions of the animals seen, have been investigated since 1957; however, all efforts to document the existence of the species in Kansas thus far have failed (Henderson and Little, Proc. Black-footed Ferret and Prairie Dog Workshop, South Dakota State Univ., pp. 34-40, 1973).

On 27 November 1978, one of us (Boggess) found the skull and left mandible of a black-footed ferret on the Larry Huck Ranch, $47 \mathrm{~km} \mathrm{S,} 6 \mathrm{~km}$ W Grinnell (T15S, R30W, NW1/4 Sec. 31), Gove Co., Kansas. The skull was on the mound of an active burrow in an isolated colony of blacktailed prairie dogs (Cynomys ludovicianus), which occupied approximately 10 ha of rangeland on the west side of a rugged canyon known as "Hell's Bar." Skulls of one adult and three juvenile prairie dogs were associated with that of the ferret on the same mound.

The ferret skull (greatest length, $68.1 \mathrm{~mm}$ ) was judged to be that of a subadult male (less than one year of age) which had been dead for at least two years (E. R. Hall, pers. comm.). We were unable to obtain precise information regarding previous attempts to control the number of prairie dogs on this ranch, but ascertained that the owner fumigated at least some burrows in spring or summer of 1977. Apparently the ferret died in the burrow, perhaps as recently as 1977, and later was removed by immigrant prairie dogs which reoccupied the burrow.

The prairie dog town was searched (by Boggess) on several occasions, both with and without snow on the ground, but no evidence of current occupation by ferrets was found. The skull (housed in the Museum of the High Plains) represents the first black-footed ferret found in Kansas in more than two decades, and is reason to hope that isolated populations of the species might persist in the state.

Edward K. Boggess ${ }^{1}$, F. Robert Henderson ${ }^{1}$, AND Jerry R. ChOATE ${ }^{2}$, ${ }^{1}$ Division of Extension, Kansas State University, Manhattan, KS 66506, and ${ }^{2}$ Museum of the High Plains, Fort Hays State University, Hays, KS 67601. Submitted 4 April 1979. Accepted 10 January 1980.

J. Mamm., 61(3):571, 1980 